\title{
Readiness to engage in treatment decision-making during initial surgical oncology consultation for early stage breast cancer
}

\author{
Angela J ukkala ${ }^{1}$, Deborah K. Walker ${ }^{1}$, Helen Krontiras ${ }^{2}$, Andres Azuero ${ }^{1}$, Karen Meneses ${ }^{1}$ \\ 1. School of Nursing, University of Alabama at Birmingham, Birmingham, AL, USA. 2. School of Medicine, University of \\ Alabama at Birmingham, Birmingham, AL, USA.
}

Correspondence: Angela Jukkala. Address: School of Nursing, University of Alabama at Birmingham, 1720 2nd Ave South, NB 312, Birmingham, AL 35294-1210, USA. Email: jukkalaa@uab.edu

Received: January 13, 2013

Accepted: April 3, 2013

Online Published: April 22, 2013

DOI : $10.5430 /$ cns.v1n2p69

URL: http://dx.doi.org/10.5430/cns.v1n2p69

\begin{abstract}
Following diagnosis with early stage breast cancer (ESBC), many difficult treatment decisions must be made. Due to the preference sensitive nature of the surgical treatment decision for ESBC, survivors need adequate treatment knowledge and the opportunity to reflect on personal preferences for expected treatment outcomes. The purpose of this study was to explore factors influencing women's readiness to engage in surgical treatment decision-making during their initial consultation for ESBC including: (1) knowledge of ESBC and surgical treatment options, 2) health literacy, (3) decision conflict; and (4) preferred treatment decision-making role. The majority of women had knowledge deficits, with only one answering all 7 items on the ESBC knowledge scale correctly. Those with low levels of health literacy had significantly lower levels of knowledge $(p<.05)$. African American women were more likely to have lower levels of knowledge, and significantly more likely to have limited health literacy $(p=.05)$. Women with lower levels of knowledge had higher levels of decision conflict $(p<.05)$. The majority preferred a patient-centered or active role in decision-making; however, they were poorly prepared for meaningful participation.As informed participation in treatment decision-making is a tenet of patient-centered care, this finding is problematic and likely contributes to poor healthcare outcomes, especially for at-risk groups of women with ESBC.
\end{abstract}

\section{Key words}

Breast cancer, Decision-making, Knowledge, Health literacy

\section{I ntroduction}

Each year over 190, 000 women are diagnosed with early stage breast cancer (ESBC) ${ }^{[1]}$. During this difficult time, many treatment decisions with life-long consequences must be made. One decision that most will make is for that of surgical treatment. Women have the option of choosing either breast conserving surgery with radiation or mastectomy, as 
guidelines and consensus statements emphasize the two options are equivalent in terms of survival ${ }^{[2]}$. During the initial consultation, topics such as surgical treatment options, prognosis, risks, and treatment outcomes are discussed ${ }^{[3]}$; surgical treatment plans will be developed during this initial consultation as well.

The role of patients in treatment decision-making has evolved from that of being a passive recipient to one of equal power with healthcare professionals ${ }^{[4]}$. This is particularly true when the decision is preference sensitive (i.e. care situations in which two or more treatment options are considered medically equivalent) such as the one for the surgical treatment of ESBC. However, assuming an active role and achieving good healthcare outcomes is dependent upon the patient having a sound understanding of the risks and benefits of treatment options. Further, women need the opportunity to reflect on how these options might be personally experienced within the context of their lives ${ }^{[5]}$. Healthcare system barriers to shared decision-making include lack of reimbursement to adopt shared decision-making under the existing fee-for-service payment system; limited understanding of how best to educate professionals to participate in shared decision-making; and clinician concerns about malpractice liability ${ }^{[6]}$. As a result of patient, healthcare professional, and system barriers, broad implementation of shared decision-making in the practice setting has not yet been accomplished ${ }^{[7]}$.

With the diagnosis of breast cancer invoking strong feelings of uncertainty, women often seek health information to better cope with diagnosis, regain a sense of control, increase their confidence, and to support treatment decision-making ${ }^{[8]}$. Nonetheless, prior research has consistently identified substantial gaps in women's knowledge of treatment for ESBC $^{[9-12]}$. Across these studies, women were most likely to have erroneous knowledge about survival and recurrence, information considered foundational to understanding ESBC treatment options. Misconceptions of ESBC and surgical treatment likely contribute to less than optimal health care and subsequent outcomes as treatment decisions are made on limited or faulty information. Conversely, adequate breast cancer treatment knowledge is associated with increased satisfaction with care, improved survival ${ }^{[13]}$ and higher levels of self-efficacy when communicating with physicians ${ }^{[14]}$.

Defined as the ability to obtain, process, and understand basic health information and services, health literacy is foundational to making informed healthcare decisions ${ }^{[15]}$. Limited health literacy contributes to low quality surgical decision-making ${ }^{[16]}$ as it reduces the potential for women to understanding complex information and the probable health outcomes of complex treatment options ${ }^{[17]}$. Further, limited health literacy has a direct impact patient-physician communication, as this process is dependent upon the exchange of information using symbols, signs, and behaviors ${ }^{[18]}$.The 2003 National Assessment of Adult Literacy report highlights the prevalence of limited health literacy, with approximately 30 million Americans being identified as functionally illiterate ${ }^{[19]}$.

Regardless of the surgical treatment decision, women who retain control and make high quality informed treatment decisions have better breast cancer health outcomes ${ }^{[20]}$. A high quality surgical treatment decision is one that is informed and is concordant with a well-informed patient's preferences and personal values ${ }^{[12]}$. The purpose of this study was to explore factors influencing women's readiness to engage in surgical treatment decision-making during their initial consultation for ESBC including: (1) knowledge of ESBC and surgical treatment options, 2) health literacy, (3) decision conflict; and (4) preferred treatment decision-making role.

\section{Methods}

Mulley's conceptual framework for shared decision-making ${ }^{[21]}$ was used to guide this study. The model identifies the two key participants (patients and providers) and three types of events: decisions, clinical practice, and health outcomes. Decisions refers to the selection of treatments based upon a patient's well informed preferences for health outcomes; 
clinical practice refers to where treatment is implemented; and health outcomes refers to those outcomes that are experienced as a result of treatment.

\subsection{Design}

This pilot study used a single site descriptive comparative design. Data were collected as part of a larger study assessing the efficacy of a surgical treatment decision aid for women diagnosed with ESBC. Participants were women seeking treatment for ESBC (Stage 1, IIA and IIB) at an interdisciplinary breast health center located within an academic health center. The study was approved by the university's institutional review board. Inclusion criteria included being age 20 or older, diagnosed with ESBC, and able to speak and write in English. Consecutive eligible women were identified by the breast health clinic nurse and invited to learn more about a study on decision-making for ESBC. A total of 37 women met inclusion criteria and were invited to participate in the study. Two women declined participation leaving a final sample size of 35 (95\%). Following provision of written informed consent, baseline data were collected prior to seeing members of the interprofessional team for the consultation.

\subsection{Instruments}

Demographic data were collected with an instrument designed for that purpose. Preferred treatment decision-making role was determined through use of the 5 item Control Preferences Scale ${ }^{[2]}$. Participants were asked to choose the response that best describes their preferred role when making medical treatment decisions: (a) I prefer my doctor make the treatment decision with little input from me; (b) I prefer my doctor make the treatment decision but seriously consider my opinion; (c) I prefer my doctor and I make the treatment decision together; (d) I prefer to make the treatment decision after seriously considering my doctor's opinion; or (e) I prefer to make the treatment decision with little input from my doctor. For the purpose of these analyses, responses were recoded into three categories: (1) physician- based (options a or b); (2) shared/collaborative (option c); or (3) patient-based (options d or e).

Health literacy was examined using the 6 item Newest Vital Sign ${ }^{[15]}$. Scores of 3 or below indicate being at-risk for limited health literacy while scores greater than 4 indicate adequate health literacy. The Newest Vital Sign has good internal consistency ( $\alpha=0.76$ for all items combined). Knowledge of ESBC and surgical treatment was measured using 7 multiple choice items from an existing survey ${ }^{[11]}$. Content and face validity of the 7 item Knowledge of ESBC instrument was established through expert review (surgical oncologist, 2 oncology nurse researchers, and 1 oncology nurse expert). A total knowledge score was calculated (range, 0-7).

Decision conflict was measured using the 16- item Decision Conflict Scale (O'Connor, 2003) which has anchors of 'strongly agree', 'agree’, 'neither agree not disagree', 'disagree', or ‘strongly disagree'. Mean subscale conflict domains include informed, values clarification, support, uncertainty, and effective decision. Possible total and subscale scores (calculated) can range from 0 (no decision conflict) to 100 (high level of decision conflict). Total or subscale scores greater than 37.5 indicate high decisional conflict which may result in decision delay and/or uncertainty about decision implementation. Scores less than 25 indicate minimal decision conflict and are associated with being able to make high quality treatment related decisions. The decision conflict scale has good internal consistency $(\alpha=0.78$ for all items combined). Surgical treatment decision intent was measured using one item that asked "Which surgical treatment option do you prefer?” with choices of ‘breast conserving surgery', 'mastectomy’ or ‘unsure’.

\subsection{Data analysis}

Demographic characteristics were summarized and questionnaire responses and frequencies were tabulated. Mean scores 
and subscale scores were calculated. Independent samples t-tests were performed to examine mean differences in knowledge of ESBC based on level of health literacy (at-risk for limited vs. adequate), race (African American vs. Caucasian), and decision conflict (low vs. high). For all statistical tests conducted, significance was set at the 0.05 level. Due to the exploratory rather than confirmatory nature of the project, no correction for multiple testing was applied.

\section{Results}

Mean participant age was 61.77 years $(S D=10.79)$, ranging from 32 to 82 years. Further demographic characteristics are presented in Table 1. In regard to preferred role in treatment decision-making, nine (25.7\%) women preferred to engage in patient-based decision-making, 13 (37.1\%) preferred a collaborative approach to decision-making, and 12 (34.3\%) preferred a physician- based decision-making. Preferred decision-making role did not vary based upon level of knowledge or health literacy.

Table 1. Sample characteristics

\begin{tabular}{|c|c|c|}
\hline Characteristics & $n$ & $\%$ \\
\hline \multicolumn{3}{|l|}{ Age ( years) $(\mathrm{N}=35)$} \\
\hline $30-40$ & 1 & 2.9 \\
\hline $40-50$ & 8 & 22.9 \\
\hline $50-60$ & 7 & 20.0 \\
\hline $60-70$ & 15 & 42.6 \\
\hline$>71$ & 4 & 11.4 \\
\hline \multicolumn{3}{|l|}{ Race $(\mathbf{N}=35)$} \\
\hline African American & 6 & 17.1 \\
\hline Caucasian & 28 & 80.0 \\
\hline Asian & 1 & 2.9 \\
\hline \multicolumn{3}{|l|}{ Educational level ( $N=34)$} \\
\hline High school graduate or less & 9 & 25.7 \\
\hline Some college & 14 & 40.0 \\
\hline College graduate & 11 & 31.4 \\
\hline \multicolumn{3}{|l|}{ Marital Status (N = 35) } \\
\hline Divorced & 6 & 17.1 \\
\hline Married & 24 & 68.6 \\
\hline Single or never married & 1 & 2.9 \\
\hline Widowed & 4 & 11.4 \\
\hline \multicolumn{3}{|l|}{ Personal income $(\mathrm{N}=35)$} \\
\hline$\leq 10,000$ & 2 & 5.7 \\
\hline 10,001 to 20,000 & 5 & 14.3 \\
\hline 20,001 to 30,000 & 2 & 5.7 \\
\hline 30,001 to 40,000 & 3 & 8.6 \\
\hline$>50,000$ & 15 & 42.9 \\
\hline Prefer not to respond & 8 & 22.9 \\
\hline Health insurance $(\mathrm{N}=34)$ & 34 & 100.0 \\
\hline
\end{tabular}

Note. Because of rounding, not all percentages total 100. 
Participant mean health literacy score was $3.81(S D=1.79$; range, 0 - 6) with approximately 2/3 of participants having adequate health literacy ( $n=22 ; 62.9 \%)$. Women at-risk for limited health literacy ( $n=10 ; 28.6 \%)$ had significantly lower knowledge scores than those with adequate health literacy $(M=2.0 ; S D=1.94$ vs. $M=3.54 ; S D=1.60)(t=2.37 ; p=.02)$. African American women were significantly more likely to be identified as being at risk for limited health literacy than their Caucasian counterparts $(M=2.5 ; S D=2.17$ vs. $M=4.04 ; S D=1.56)(t=-2.01 ; p=.05)$. Though health literacy scores were lower in women with lower educational achievement (high school graduate or less) $(M=3.10, S D=2.28$ vs. $M$ $=4.14 S D=1.45$ ), they were not significantly different. Health literacy did not vary based on educational level. The Newest Vital Sign scale was found to have fair internal consistency $(\alpha=0.69)$. The mean Knowledge of ESBC score was $3.49(S D=1.96$; range, 0 to 7$)$. Only $1(8.6 \%)$ BCS answered all seven times correctly, with the majority $(n=20 ; 57.1 \%)$ answering 4 or fewer items correctly. Overall the percentage of women who responded correctly to individual items ranged from $22.9 \%$ to $74.3 \%$. Table 2 shows the percentage of participants responding correctly to each item. Though not statistically significant, African American women had lower knowledge scores than Caucasian women $(M=2.5 ; S D=$ 2.81 vs. $M=3.69 ; S D=1.75)$. The knowledge scale was found to have fair internal consistency $(\alpha=0.69)$.

The mean decision conflict score regarding surgical treatment for ESBC was 48.05 (SD = 23.08)(Table 3). Almost $3 / 4$ of participants had a decision conflict score greater than $37.5(n=26 ; 74.3 \%)$ and only $5(11.4 \%)$ has scores $>25$. Mean subscale conflict scores are: Informed $=52.30$; Values Clarification $=50.0$; Support $=35.23$; Uncertainty $=59.29$; and Effective Decision $=44.82$. Individual item score indicating the highest level of conflict was "I have enough advice to make a choice" $(M=3.43, S D=1.14)$. Individual item score indicating the least amount of conflict was "I am choosing without pressure from others $(M=1.88 ; S D=0.96)$. Women with higher levels of decision conflict (scores > 37.5) had significantly lower knowledge levels than those with lower levels of decision conflict ( $M=3.07 ; S D=2.05$ vs. $M=4.66$; $S D=1.11)(t=-2.19 ; p=03)$. Most women verbalized a surgical treatment decision intent at baseline $(n=25 ; 71.5 \%)$ with 15 (42.9\%) choosing breast conserving surgery and 10 (28.6\%) choosing mastectomy. There was no difference between women who verbalized a treatment intent prior to the initial consultation and those who had not based on knowledge, health literacy or decision conflict.

Table 2. Knowledge of early stage breast cancer and treatment $(\mathrm{N}=35)$

\begin{tabular}{|c|c|c|}
\hline Item & Correct response & $\begin{array}{l}\text { Participants } \\
\text { answering } \\
\text { correctly }\end{array}$ \\
\hline In most cases, radiation therapy follows which form of treatment? & Breast conserving surgery & $16(45.7 \%)$ \\
\hline Generally, radiation therapy lasts? & 6 weeks & $13(37.1 \%)$ \\
\hline In early stages of breast cancer, cancer cells may be found & In other parts of the body & $8(22.9 \%)$ \\
\hline $\begin{array}{l}\text { Generally, drug therapy is needed to kill remaining cancer cells } \\
\text { after which form of treatment? }\end{array}$ & Both lumpectomy and mastectomy & $16(45.7 \%)$ \\
\hline When breast cancer is found early, chances for survival are & Excellent & $26(74.3 \%)$ \\
\hline A patient's best chance for survival is with which procedure? & $\begin{array}{l}\text { Both BCS with radiation and mastectomy } \\
\text { offer the same chance for survival }\end{array}$ & $16(45.7 \%)$ \\
\hline Radiation therapy for early stage breast cancer & May redden some of the skin & $24(68.6 \%)$ \\
\hline
\end{tabular}

\section{Discussion}

Our knowledge of how prepared women diagnosed with ESBC are to make treatment decisions during their initial oncology consultation continues to grow and evolve. In this study, we explored patient characteristics that influence 
readiness to engage in surgical treatment decision-making for ESBC. Findings indicate that most women are poorly prepared for meaningful participation in shared treatment decision-making.

Table 3. Decision conflict $(\mathrm{N}=35)$

\begin{tabular}{|c|c|c|c|c|c|c|c|c|}
\hline \multirow[t]{2}{*}{ Item } & $\begin{array}{l}\text { Strongly } \\
\text { Agree }\end{array}$ & Agree & $\begin{array}{l}\text { Neither } \\
\text { Agree or } \\
\text { Disagree }\end{array}$ & Disagree & $\begin{array}{l}\text { Strongly } \\
\text { Disagree }\end{array}$ & Mean & $S D$ & $\alpha$ \\
\hline & $n(\%)$ & $n(\%)$ & $n(\%)$ & $n(\%)$ & $n(\%)$ & & & \\
\hline \multicolumn{8}{|l|}{ INFORMED SUBSCALE } & 0.88 \\
\hline $\begin{array}{l}\text { I know which options are available } \\
\text { to me. }\end{array}$ & $7(20.0)$ & $10(28.6)$ & $8(22.9)$ & $6(17.1)$ & $4(11.4)$ & 2.71 & & \\
\hline I know the benefits of each option. & $3(8.6)$ & $7(20.0)$ & $10(28.6)$ & $10(28.6)$ & $5(14.3)$ & 3.20 & & \\
\hline $\begin{array}{l}\text { I know the risks and side effects of } \\
\text { each option. }\end{array}$ & $3(8.6)$ & $3(8.6)$ & 13(37.1) & $10(28.6)$ & $6(17.1)$ & 3.37 & & \\
\hline \multicolumn{8}{|c|}{ VALUES CLARICIATION SUBSCALE } & 0.87 \\
\hline $\begin{array}{l}\text { I am clear about which risks and side } \\
\text { effects matter most to me. } \\
\text { I am clear about which is more }\end{array}$ & $6(17.1)$ & $5(14.3)$ & 11(31.4) & $8(22.9)$ & $5(14.3)$ & 3.03 & & \\
\hline $\begin{array}{l}\text { important to me (the benefits or the } \\
\text { risks and side effects)*. }\end{array}$ & $4(11.4)$ & $7(20.0)$ & $11(31.4)$ & $8(22.9)$ & $4(11.4)$ & 3.02 & & \\
\hline \multicolumn{8}{|l|}{ SUPPORT SUBSCALE } & 0.71 \\
\hline $\begin{array}{l}\text { I have enough support from others to } \\
\text { make a decision. }\end{array}$ & $14(40.0)$ & 13(37.1) & $6(17.1)$ & $1(2.9)$ & $1(2.9)$ & 1.91 & & \\
\hline $\begin{array}{l}\text { I am choosing without pressure from } \\
\text { others. }\end{array}$ & $14(40.0)$ & $14(40.0)$ & $5(14.3)$ & $1(2.9)$ & $1(2.9)$ & 1.88 & & \\
\hline $\begin{array}{l}\text { I have enough advice to make a } \\
\text { choice. }\end{array}$ & $2(5.7)$ & $5(14.3)$ & $11(31.4)$ & $10(28.6)$ & $7(70.0)$ & 3.43 & & \\
\hline \multicolumn{8}{|l|}{ UNCERTAINTY SUBSCALE } & 0.89 \\
\hline $\begin{array}{l}\text { I am clear about the best choice for } \\
\text { me. }\end{array}$ & $3(8.6)$ & $5(14.3)$ & 11(31.4) & $9(25.7)$ & $7(20.0)$ & 3.34 & & \\
\hline I feel sure about what to choose. & $3(8.6)$ & $7(20.0)$ & $9(25.7)$ & $6(17.1)$ & $10(28.6)$ & 3.37 & & \\
\hline This decision is easy for me to make. & $3(8.6)$ & $6(17.1)$ & $10(28.6)$ & $6(17.1)$ & $10(28.6)$ & 3.40 & & \\
\hline \multicolumn{8}{|l|}{ EFFECTIVE DECISION SUBSCALE } & 0.87 \\
\hline $\begin{array}{l}\text { I feel I have make an informed } \\
\text { decision. }\end{array}$ & $4(11.4)$ & $4(11.4)$ & $17(48.6)$ & $2(5.7)$ & $8(22.9)$ & 3.17 & & \\
\hline $\begin{array}{l}\text { My decision shows what is } \\
\text { important to me. }\end{array}$ & $6(17.1)$ & 11(31.4) & 13(37.1) & $4(11.4)$ & $1(2.9)$ & 3.37 & & \\
\hline I expect to stick with my decision. & $7(20.0)$ & $6(17.1)$ & $16(45.7)$ & $1(2.9)$ & $4(11.4)$ & 2.67 & & \\
\hline I am satisfied with my decision*. & $4(11.4)$ & $8(22.9)$ & $15(42.9)$ & $1(2.9)$ & $6(17.1)$ & 2.91 & & \\
\hline TOTAL & & & & & & 48.05 & 23.08 & 0.95 \\
\hline
\end{tabular}

Note. * indicates 1 participant did not answer item.

Items scored: strongly agree $=0$, agree $=1$, neither agree or disagree $=2$, disagree $=3$ and strongly disagree $=4$. Higher score indicates higher levels of decision conflict.

Given that the majority of women with breast cancer actively seek health information to better understand and participate 
in treatment decision-making ${ }^{[24-26]}$, findings from this and other studies ${ }^{[27,28]}$ indicating that most women have insufficient knowledge of ESBC and surgical treatment options are counterintuitive. This creates concern regarding the "suitability" (content, literacy demand graphics, layout/typography, learning stimulation and cultural appropriateness) ${ }^{[29]}$ of existing ESBC health information for its intended audience. Additional research is needed to examine women's preferred sources (e.g. internet, social networking, or video) of breast cancer health information to ensure timely access.

Almost one-third of the women in this study were at-risk for limited health literacy which likely impacted their ability to have meaningful involvement in shared decision-making ${ }^{[16,30]}$. Unfortunately, many healthcare professionals are unaware of the impact of limited health literacy on health systems or individual patients ${ }^{[31]}$. For shared decision-making to be fully implemented into clinical practice, healthcare professionals need to be knowledgeable of limited health literacy, identify patients with limited health literacy, and understand the impact of limited literacy on patient education, communication and decision-making.

African American women participating in this study were more likely to be at-risk for limited health literacy and had lower levels of treatment knowledge than Caucasian women. This is concerning as substantial variation in breast cancer treatment and health outcomes is known to exist between African American and Caucasian women ${ }^{[1]}$. African American women are less likely to receive appropriate or optimal surgical treatment ${ }^{[32,33]}$, adjuvant therapy ${ }^{[34]}$ and are less likely to be knowledgeable of the risks and benefits of surgical treatment options ${ }^{[9]}$. It is possible that persistent variation in breast cancer outcomes for African American woman may be related to the impact of limited health literacy on treatment decisions. Further research to examine the influence of health literacy on knowledge and treatment choice with African American women is needed.

Our knowledge of cognitive impairment in women with ESBC is continuing to grow ${ }^{[35]}$ revealing that subtle cognitive changes are often experienced by breast cancer survivors prior to initiation of treatment ${ }^{[36,37]}$. Cancer survivors often describe cognitive impairment in terms of symptoms such as forgetfulness, memory lapses, difficulty with problem solving, inability to focus or concentrate, and mental slowness. It is possible that subtle cognitive changes impacted participant's ability to access, understand, and utilize health information.

The vast majority of women participating in the study were experiencing decision conflict during their initial oncology consultation, a time during which treatment options will be presented and quite often treatment decisions will be made. Decision conflict refers to the psychologic discomfort that a person may experience as a result of uncertainties inherent in making a preference-sensitive treatment decision ${ }^{[38,39]}$. Individuals are more likely to experience decision conflict if they feel uninformed, are unclear about their personal values, and/or feel unsupported in making a choice or pressured to make a specific decision ${ }^{[23]}$. While information regarding treatment options can readily be shared during this visit, the opportunity to reflect upon this information may be quite limited. Across all subscales, women participating in this study had high levels of decision conflict, experiencing the most conflict in regard to being uncertain about making a treatment decision. This is not surprising given their limited knowledge ESBC and surgical treatment options. Despite limited knowledge and high levels of decision conflict, most women reported having reached a surgical treatment decision prior to arrival for their consultation. This is concerning, as it is likely these treatment decisions were made based on inadequate or faulty knowledge. Further, as they lacked requisite knowledge of treatment and expected health outcomes, the capacity to accurately reflect upon treatment options and how they might be personally experienced was simply not possible.

Consistent with findings from other studies ${ }^{[40-42]}$ almost two-thirds of women in this study preferred an active role (collaborative or patient- based) in treatment decision-making. Women who are involved in decision-making at a level that is consistent with or greater than their preferred role have better overall decision related outcomes ${ }^{[43]}$. Conversely, failure 
to achieve the preferred decision-making role is known to lower satisfaction with care provided and increase anxiety ${ }^{[44]}$. Unfortunately, the actual role patients assume in treatment decision- making is often inconsistent with their preferred role ${ }^{[27,41,45]}$.

It has been posited that imposing “choice” on patients may be as detrimental as imposing treatment decisions ${ }^{[44]}$, with many studies indicating that a sizeable minority of women prefer to engage in physician-based treatment decision-making ${ }^{[43,46,47]}$. Further, individual role preferences in treatment decision-making are dynamic and may change between treatment decisions across survivorship ${ }^{[48]}$. Thus it is imperative that healthcare professionals providing care for ESBC survivors elicit patient's decision-making preferences throughout survivorship. Further research is needed to develop effective and efficient screening tools to elicit and incorporate patient decision-making preferences into clinical practice.

Though shared decision-making has been identified as an essential component of patient-centered care ${ }^{[7]}$, barriers to implementation within the healthcare system are pervasive ${ }^{[49]}$. Recognized barriers within the practice setting to shared decision-making include limited awareness by healthcare professionals, time constraints, and lack of applicability due to patient characteristics and /or clinical situations ${ }^{[50,51]}$. Interventions that have been identified to improve adoption of shared decision-making include healthcare provider education (continuing and preparatory), legislation to provide financial incentives to those including shared decision-making in the provision of care, and use of patient decision aids to prepare patients to engage in shared decision-making are clearly needed as well ${ }^{[7,51,52]}$.

\section{Limitations}

The study utilized a relatively small convenience sample, thus study findings cannot be generalized beyond those in this study. Further, during the difficult timeframe immediately following diagnosis, emotional distress may have limited participant breast cancer health information recall and performance on the literacy assessment. However, findings from this study are consistent with those of others examining ESBC surgical treatment knowledge ${ }^{[9,11,53]}$. Findings from this study also expand our knowledge of shared decision-making for African American women diagnosed with ESBC.

\section{Conclusions}

Women diagnosed with ESBC need access to high quality health information prior to their initial surgical consultation with time to carefully reflect upon different treatment options and how they might be personally experienced. Findings from this study suggest that while women diagnosed with ESBC prefer to have an active role in treatment decision-making; they lack the requisite knowledge to support meaningful engagement. As inadequate knowledge is associated with high levels of decision conflict and decision regret following treatment implementation ${ }^{[54]}$, ensuring women have access to high quality health information is essential. Additional research is needed to identify and eliminate barriers (individual, healthcare professional and healthcare system) to patients' ability to access and utilize health information.

\section{References}

[1] American Cancer Society, Cancer facts \& figures 2012[Internet]. [cited 2013 April 9]. Available from http://www.cancer.org/acs/groups/content/@epidemiologysurveilance/documents/document/acspc-031941.pdf

[2] National Institute of Health. Treatment of early-stage breast cancer. Bethesda, MD1990. 
[3] Brown RF, Hill C, Burant CJ, Siminoff LA. Satisfaction of early breast cancer patients with discussions during initial oncology consultations with a medical oncologist. Psychooncology. 2009;18(1):42-49. PMid:18484569 http://dx.doi.org/10.1002/pon.1376

[4] Barr D. Reinvesting in the doctor--patient relationship in the coming era of scarcity. Am J Bioeth. 2006;6(1):33-34. PMid:16423785 http://dx.doi.org/10.1080/15265160500394580

[5] Holmes-Rovner M, Nelson WL, Pignone M, et al. Are patient decision aids the best way to improve clinical decision making? Report of the IPDAS Symposium. Med Decis Making. 2007;27(5):599-608. PMid:17873257 http://dx.doi.org/10.1177/0272989X07307272

[6] Malley AS, Carrier E, Docteur E, Shmerling AC, Rich EC. Policy options to encourage patient=physician shared decision making[Internet]. 2011[cited 2013 April 9]. Available from http://www.nihcr.org/Shared-Decision-Making.

[7] Barry MJ, Edgman-Levitan S. Shared decision making--pinnacle of patient-centered care. N Engl J Med. 2012;366(9):780-781. PMid:22375967 http://dx.doi.org/10.1056/NEJMp1109283

[8] Rees CE, Bath PA. Information-seeking behaviors of women with breast cancer. Oncol Nurs Forum. 2001;28(5):899-907. PMid:11421149

[9] Hawley ST, Fagerlin A, Janz NK, Katz SJ. Racial/ethnic disparities in knowledge about risks and benefits of breast cancer treatment: does it matter where you go? Health Serv Res. 2008;43(4):1366-1387. PMid:18384361 http://dx.doi.org/10.1111/j.1475-6773.2008.00843.x

[10] Fagerlin A, Lakhani I, Lantz PM, et al. An informed decision? Breast cancer patients and their knowledge about treatment. Patient Educ Couns. 2006; 64(1-3):303-312. PMid:16860523 http://dx.doi.org/10.1016/j.pec.2006.03.010

[11] Street RL, Jr., Voigt B, Geyer C, Jr., Manning T, Swanson GP. Increasing patient involvement in choosing treatment for early breast cancer. Cancer. 1995;76(11):2275-2285. http://dx.doi.org/10.1002/1097-0142(19951201)76:11<2275::AID-CNCR2820761115>3.0.CO;2-S

[12] Sepucha KR, Belkora JK, Chang Y, et al. Measuring decision quality: psychometric evaluation of a new instrument for breast cancer surgery. BMC Med Inform Decis Mak. 2012;12:51. PMid:22681763 http://dx.doi.org/10.1186/1472-6947-12-51

[13] Chen JY, Diamant AL, Thind A, Maly RC. Determinants of breast cancer knowledge among newly diagnosed, low-income, medically underserved women with breast cancer. Cancer. 2008;112(5):1153-1161. PMid:18189306 http://dx.doi.org/10.1002/cncr.23262

[14] Maly RC, Frank JC, Marshall GN, DiMatteo MR, Reuben DB. Perceived efficacy in patient-physician interactions (PEPPI): validation of an instrument in older persons. J Am Geriatr Soc. 1998;46(7):889-894. PMid:9670878

[15] Weiss BD, Mays MZ, Martz W, et al. Quick assessment of literacy in primary care: the newest vital sign. Ann Fam Med. 2005;3(6):514-522. PMid:16338915 http://dx.doi.org/10.1370/afm.405

[16] Amalraj S, Starkweather C, Nguyen C, Naeim A. Health literacy, communication, and treatment decision-making in older cancer patients. Oncology (Williston Park). 2009; 23(4):369-375. PMid:19476267

[17] Polacek GN, Ramos MC, Ferrer RL. Breast cancer disparities and decision-making among U.S. women. Patient Educ Couns. 2007;65(2):158-165. PMid:16870385 http://dx.doi.org/10.1016/j.pec.2006.06.003

[18] Barnato AE, Llewellyn-Thomas HA, Peters EM, Siminoff L, Collins ED, Barry MJ. Communication and decision making in cancer care: setting research priorities for decision support/patients' decision aids. Med Decis Making. 2007;27(5):626-634. PMid:17873249 http://dx.doi.org/10.1177/0272989X07306788

[19] Kutner MA, National Center for Education Statistics. Literacy in everyday life : results from the 2003 National Assessment of Adult Literacy. Washington, DC: National Center for Education Statistics; 2007.

[20] Dunaway FW, Hueston WJ, Clevinger L. An exploratory study of the experiences of rural women with breast cancer. J Ky Med Assoc. 1995;93(6):241-245. PMid:7622959

[21] Mulley AJ. Methodologic issues in the application of effectiveness and outcomes research to clinical practice. Effectiveness and outcomes in health care. Washington, D.C. 1990.

[22] Degner L, Sloan JA, Venkatesh P. The Control Preferences Scale. Can J Nurs Res. 1997; 29(3):21-43. PMid:9505581

[23] O'Connor AM. User manual: Decisional Conflict Scale. Ottawa Hospital Research Institute[Internet]. 2003[cited 2013 April 19]. Available from www.ohri.ca/decisionaid

[24] Degner LF, Kristjanson LJ, Bowman D, et al. Information needs and decisional preferences in women with breast cancer. JAMA. 1997; 277(18):1485-1492. PMid:9145723 http://dx.doi.org/10.1001/jama.1997.03540420081039

[25] Keating NL, Guadagnoli E, Landrum MB, Borbas C, Weeks JC. Treatment decision making in early-stage breast cancer: should

Published by Sciedu Press 
surgeons match patients' desired level of involvement? J Clin Oncol. 2002; 20(6):1473-1479.

PMid:11896094 http://dx.doi.org/10.1200/JCO.20.6.1473

[26] O'Leary KA, Estabrooks CA, Olson K, Cumming C. Information acquisition for women facing surgical treatment for breast cancer: influencing factors and selected outcomes. Patient Educ Couns. 2007; 69(1-3):5-19.

PMid:17889495http://dx.doi.org/10.1016/j.pec.2007.08.002

[27] Hawley ST, Lantz PM, Janz NK, et al. Factors associated with patient involvement in surgical treatment decision making for breast cancer. Patient Educ Couns. 2007; 65(3):387-395.

PMid:17156967 http://dx.doi.org/10.1016/j.pec.2006.09.010

[28] Janz NK, Wren PA, Copeland LA, Lowery JC, Goldfarb SL, Wilkins EG. Patient-physician concordance: preferences, perceptions, and factors influencing the breast cancer surgical decision. J Clin Oncol. 2004; 22(15):3091-3098. PMid:15284259 http://dx.doi.org/10.1200/JCO.2004.09.069

[29] Finnie RK, Felder TM, Linder SK, Mullen PD. Beyond reading level: a systematic review of the suitability of cancer education print and Web-based materials. J Cancer Educ. 2010; 25(4):497-505.

PMid:20237884 http://dx.doi.org/10.1007/s13187-010-0075-0

[30] Oates DJ, Silliman RA. Health literacy: improving patient understanding. Oncology (Williston Park). 2009; 23(4): 376,379.

[31] Jukkala A, Deupree JP, Graham S. Knowledge of limited health literacy at an academic health center. J Contin Educ Nurs. 2009; 40(7):298-302; quiz 303-294, 336.

[32] Haggstrom DA, Quale C, Smith-Bindman R. Differences in the quality of breast cancer care among vulnerable populations. Cancer. Dec 1 2005; 104(11):2347-2358. PMid:16211547 http://dx.doi.org/10.1002/cncr.21443

[33] Lund MJ, Brawley OP, Ward KC, Young JL, Gabram SS, Eley JW. Parity and disparity in first course treatment of invasive breast cancer. Breast Cancer Res Treat. 2008; 109(3):545-557. PMid:17659438 http://dx.doi.org/10.1007/s10549-007-9675-8

[34] Bickell NA, Wang JJ, Oluwole S, et al. Missed opportunities: racial disparities in adjuvant breast cancer treatment. J Clin Oncol. 2006; 24(9):1357-1362. PMid:16549830 http://dx.doi.org/10.1200/JCO.2005.04.5799

[35] Pullens MJ, De Vries J, Roukema JA. Subjective cognitive dysfunction in breast cancer patients: a systematic review. Psychooncology. 2010; 19(11):1127-1138. PMid:20020424 http://dx.doi.org/10.1002/pon.1673

[36] Kesler SR, Kent JS, O'Hara R. Prefrontal cortex and executive function impairments in primary breast cancer. Arch Neurol. Nov 2011; 68(11):1447-1453.

PMid:22084128 http://dx.doi.org/10.1001/archneurol.2011.245

[37] Ahles TA, Saykin AJ, McDonald BC, et al. Cognitive function in breast cancer patients prior to adjuvant treatment. Breast Cancer Res Treat. 2008; 110(1):143-152. PMid:17674194 http://dx.doi.org/10.1007/s10549-007-9686-5

[38] Brehaut JC, O'Connor AM, Wood TJ, et al. Validation of a decision regret scale. Med Decis Making. Jul-Aug 2003;23(4):281-292. PMid:12926578 http://dx.doi.org/10.1177/0272989X03256005

[39] O'Connor AM. Validation of a decisional conflict scale. Med Decis Making. 1995;15(1):25-30. PMid:7898294 http://dx.doi.org/10.1177/0272989X9501500105

[40] Nakashima M, Kuroki S, Shinkoda H, Suetsugu Y, Shimada K, Kaku T. Information-seeking experiences and decision-making roles of Japanese women with breast cancer. Fukuoka Igaku Zasshi. 2012; 103(6):120-130. PMid:22880284

[41] Tariman JD, Berry DL, Cochrane B, Doorenbos A, Schepp K. Preferred and actual participation roles during health care decision making in persons with cancer: a systematic review. Ann Oncol. 2010; 21(6):1145-1151. PMid:19940010 http://dx.doi.org/10.1093/annonc/mdp534

[42] Hubbard G, Kidd L, Donaghy E. Preferences for involvement in treatment decision making of patients with cancer: a review of the literature. Eur J Oncol Nurs. 2008;12(4):299-318.

PMid:18486552 http://dx.doi.org/10.1016/j.ejon.2008.03.004

[43] Brown R, Butow P, Wilson-Genderson M, Bernhard J, Ribi K, Juraskova I. Meeting the decision-making preferences of patients with breast cancer in oncology consultations: impact on decision-related outcomes. J Clin Oncol. 2012; 30(8):857-862.

PMid:22312102 http://dx.doi.org/10.1200/JCO.2011.37.7952

[44] Gattellari M, Butow PN, Tattersall MH. Sharing decisions in cancer care. Soc Sci Med. Jun 2001;52(12):1865-1878. http://dx.doi.org/10.1016/S0277-9536(00)00303-8

[45] Degner L. Patient participation in treatment decision making. Axone. 1992; 14(1):13-14. PMid:1476947 
[46] Butow PN, Dunn SM, Tattersall MH, Jones QJ. Patient participation in the cancer consultation: evaluation of a question prompt sheet. Ann Oncol. 1994; 5(3):199-204. PMid:8186168

[47] Livaudais JC, Franco R, Fei K, Bickell NA. Breast Cancer Treatment Decision-Making: Are We Asking Too Much of Patients? J Gen Intern Med. 2012. PMid:23229908

[48] Butow PN, Maclean M, Dunn SM, Tattersall MH, Boyer MJ. The dynamics of change: cancer patients' preferences for information, involvement and support. Ann Oncol. 1997; 8(9):857-863. PMid:9358935 http://dx.doi.org/10.1023/A:1008284006045

[49] Oshima Lee E, Emanuel EJ. Shared decision making to improve care and reduce costs. N Engl J Med. 2013;368(1):6-8. PMid:23281971 http://dx.doi.org/10.1056/NEJMp1209500

[50] Legare F, Ratte S, Gravel K, Graham ID. Barriers and facilitators to implementing shared decision-making in clinical practice: update of a systematic review of health professionals' perceptions. Patient Educ Couns. 2008;73(3):526-535. PMid:18752915 http://dx.doi.org/10.1016/j.pec.2008.07.018

[51] Legare F, Ratte S, Stacey D, et al. Interventions for improving the adoption of shared decision making by healthcare professionals. Cochrane Database Syst Rev. 2010(5): CD006732. PMid:20464744

[52] Simmons M, Hetrick S, Jorm A. Shared decision-making: benefits, barriers and current opportunities for application. Australas Psychiatry. 2010;18(5):394-397. PMid:20863175 http://dx.doi.org/10.3109/10398562.2010.499944

[53] Nissen MJ, Tsai ML, Blaes AH, Swenson KK, Koering S. Effectiveness of treatment summaries in increasing breast and colorectal cancer survivors' knowledge about their diagnosis and treatment. J Cancer Surviv. 2013. PMid:23417167 http://dx.doi.org/10.1007/s11764-012-0261-7

[54] Fernandes-Taylor S, Bloom JR. Post-treatment regret among young breast cancer survivors. Psychooncology. 2011; 20(5): 506-516. PMid:20878843 http://dx.doi.org/10.1002/pon.1749 